A word in explanation of this strange appearance from some of your learned contributors would, I think, be interesting.

Model School, Waterford, June I Henry P. Dowling

\section{Classes for Women at University College}

IN view of the new charter enabling the University of London to confer degrees on women, and the increased demand for a higher education of women, the council of this college have determined to provide for them systematic instruction in regular college classes.

In most subjects the junior classes for women will be distinct from those attended by male students. The senior classes will more generally be open to both sexes, and these classes, which are already open to both, as fine arts, philosophy of mind, \&c., will remain so.

Prospectuses embodying the results of this change will be ready by the 18 th inst.

University College, London

TALFOURD ELY

[Ou Rt. Petersburg correspondent, "C. S." must send us his name (in conficlence), before we can publish his last communication.]

\section{PROF. FOSEPH HENRY, LL.D.}

PROF. HENRY was born December $17 ; 1797$, at Albany, New York, where also much of his early life was passed. The year of his birth seems, however, uncertain, some authorities placing it in $\mathbf{7 9 9}$, or even later. He had at first the advantages of only a common school education. A parish library supplied him with boyish reading, and his carly tastes were in the direction of romance and the drama. He was nearly grown when the accidental possession of a copy of Robinson's "Mechanical Philosophy" turned his thoughts towards natural philosophy. After two years of work as a watchmaker, he came under the training of the Albany Academy, where he developed a degree of mathematical talent which, in 1826 , led to his selection for the dutics of instructor in mathematics in that institution. Prior to this, having had some experience in the field as a surveyor, he was associated with Amos Eaton in the Geological Survey along the line of the Erie Canal, projected and sustained by General Stephen van Rensselaer. Failing physical health led to his taking this step. $\mathrm{He}$ returned home with a robust constitution, which never failed him throughout his life.

While occupied with his duties as mathematical instructor in the academy-then in charge of Dr. $T$. Romeyn Beck--he commenced that line of investigation in electricity which resulted in the important discoveries that have made his name famous. He attended the lectures on chemistry of Dr. Beck, and assisted in the preparation of his experiments. At this time he devised and published an improved form of Wollaston's slidingscale of chemical equivalents, in which hydrogen was adopted as the radix - a contrivance which is hardly known, even by name, to the present generation of chemists. Thus, while Prof. Henry's original contributions to science were chiefly physical, his first scientific work was in the department of chemistry. His work with Dr. Beck enabled him, after his removal to Princeton-where he became professor of natural philosophy in 1832, - to take up the duties of the chemist, Dr. John Torrey, when that well-known teacher was disabled for a time by ill health.

It was in the interval between 1828 and 1837 that the most important work of his life was accomplished in the line of strictly scientific research.

If we compare the poverty of his apparatus and the poverty of his means for research and publication with the importance of the results which he reached, we may accord him a place by the side of Faraday as an experimentalist. He became the sole discoverer of one of the most singular forms of electrical induction, and was among the first, perhaps the very first, to see clearly the laws which connect the transmission of electricity with the power of the battery employed. One of the problems to which he devoted himself was that of producing mechanical effects at a great distance by the aid of an electro-magnet and a conducting wire. The horse-shoe electro-magnet, formed by winding copper wire round a bar of iron bent into the form of a $U$, had been known before his time, and it was also known that by increasing the number of coils of wire greater force could be given to the magnet, if the latter were near the battery. But when it was removed to a distance the power was found to weaken at so rapid a rate that the idea of using the electro-magnet for telegraphic purposes seemed hopeless. Henry's experiments were directed toward determining the laws of electro-motive force from which this diminution of power resulted, and led to the discovery of a relation between the number of coils of wire round the electro-magnet and the construction of the battery to work it. He showed that the very same amount of acid and zinc arranged in one way would produce entirely different effects when arranged in another, and that by increasing the number of cells in the battery there was no limit to the distance at which its effects might be felt. It only remained for some one to invent an instrument by which these effects should be made to register in an intelligible manner, to complete the electro-magnetic telegraph, and this was done by Morse. Henry himself considered the work of an inventor as wholly distinct from that of a scientific investigator, and would not protect the application of his discoveries, nor even engage in the work of maturing such applications. He never sought to detract from Morse's merits as the, inventor of the magneto-electric tclegraph, but did on one occasion, under legal process, give a history of the subject which was not favourable to Morse's claim to the exclusive use of the electro-magnet for telegraphic purposes. Somo feeling was thus excited; but Henry took no other part in the controversy than to ask an investigation of some charges against himself contained in an article of Morse's.

The results of these researches are chiefly recorded in the Transactions of the Albany Institute, the rolumes of the American Fournal of Science and Arts for the period, and the Transactions of the American Pbilosophical Society. His "Contributions to Electricity and Magnetism" were collected in a separate volume in 1839 . The analysis of these important researches, and the discussion of the questions of priority connected with them, will be the duty of the academician to whom shall be assigned the preparation of a memoir or eulogy of the distinguished author.

The nemoir in the American Fournal gives a list of twenty-two memoirs and discoveries by Prof. Henry. To these papers should be added an important series of communications, made chiefly to the National Academy of Sciences during the past four or five years, upon the laws of acoustics as developed in the course of investigations conducted for the Light-House Service in order to determine the various conditions involved in the transmission of fog-signals. These investigations have been carried forward mainly in government vessels, and occupied Prof. Henry's close personal attention during many weeks of each season.

Besides these cxperimental additions to physical science, Prof. Henry is the author of thirty reports, between the years 1846 and 1876 , giving an exposition of the annual operations of the Smithsonian Institution. He has also published a series of essays on meteorology in the Patent Cffice Reports, which, along with an exposition of established principles, contain many new suggestions, and, among others, the origin of the development of electricity, as exhibited in the thunderstorm.

In $183 ;$ he visited Europe and made the acquaintance 
of Faraday, Wheatstone, Bailey, and other eminent physicists, discussing with Wheatstone their projects for an electric telegraph. He returned to his lectures with the zest and vigour acquired by this exchange of views with men of like pursuits with himself, and held his place as the foremost of American scientific teachers until i 846, when he was called to an entirely different sphere of activity.

Ten years before Congress had accepted, by a solemn act, the curious bequest of James Smithson, made to the United States in trust, "to found at Washington an establishment for the increase and diffusion of knowledge among men." The will gave no indications whatever as to the details of the proposed establishment, and long consideration was therefore necessary before the Government could decide upon its organisation. It was not until i 846 that a definite plan of organisation was established by law. When this was done Prof. Henry was at once looked upon as pre-eminently the man to be the principal executive officer of the institution. He accepted the position with " reluctance, fear, and trembling," upon the urgent solicitation of Prof. Bache. From the beginning two different views of the proper direction in which the energies of the establishment should be devoted have been entertained. There was a scientific party, which held that the operations of the estabishment should be confined strictly within the limits prescribed by the donor, and in the sense in which he himself, as a scicntific investigator, would naturally have construed his own words - in fact, that it should be entirely an institution for scientific research and publication. Another party was desirous of giving it a larger scope and wider range, including literature and art as well as science. The new secretary, of course, sympathised entirely with the scientific party, who considered most of the objects proposed by the other party as foreign to the proper purpose of the institution, and the expenditure of money upon them as contrary to the expressed intention of the donor. The whole policy of Henry was directed towards diminishing, as far as possible, the expenditure of the Smithsonian fund upon the library, the builcting, the museum, and art-gallery, by having these several objects provided for in other ways. He got the library removed to the Capitol and deposited in the Library of Congress, and the art-gallery superseded by the Corcoran Gallery of Art. The impropriety of charging the Smithsonian fund with the support of the governmental collections was so obvious that Congress has for several years provided for the maintenance of the National Muscum, as it has now become, in connection with the institution. He aimed at a complete separation of the museum from the institution; the Government leasing the building for the use of the former, whilc the latter should find more modest and appropriate but less expensive quarters. This project, however, he did not live to carry out.

Henry was, of course, the authority most frequently and regularly consulted by the Government on all questions which arose involving applications of science or of scientific principles. His greatest services to the Government were rendered as a member of the Light-House Board, a position which he held from the time the Board was organised. His principal duties were at first to inquire into the various methods of illumination, and especially to test the oils proposed for this purpose. Of late years he began to investigate the subject of fogsignals, which led to a very extended series of cxperimental researches on the causes which influence the propagation of sound through the air, and which sometimes render it inaudible at comparatively short distances. These experiments were mostly published in the annual reports of the Light-House Board.

The idea of using the telegraph for communicating the weather reports originated with Professor Henry, and was put in operation at the Institution at an early period of his connection with it.

It was while engaged in the discharge of certain experimental work on Staaten Island last December, connected with the photometric laboratory of the Light-House Board, that he experienced a partial paralysis, which yielded soon to treatment, but was doubtless the precursor of the nephritic attack to which he succumbed. In April he presided at the opening meeting of the session of the National Academy of Sciences, held in the rooms of the Secretary of the Smithsonian, and submitted an address to his associates, read by the Home Secretary, recounting with touching simplicity his recent decline of power, and expressing his desire to be relieved from the cares of the office of President. As a mark of affectionate respect, the Academy unanimously requested him to retain this post during his life-leaving the duties to be discharged by the Vice-President. It was on this occasion that the announcement was made to the Academy, by Prof. Henry, and, subsequently, in fuller details, by Prof. Fairman Rogers, the treasurer, of the creation of an endowment to be called "the Joseph Henry Fund." This fund consists of forty thousand dollars, securely invested, the income of which is for the support of Prof. Henry and that of his family, during the life of the latest survivor. Afterwards the fund is to be transferred, in trust, to the National Academy of Sciences, the income to be for ever devoted to scientific research. No more graceful and well-merited tribute of respect and affection was ever bestowed upon a man of science by the spontaneous offerings of personal friends and associates. Alas! that its honoured object should have remained so brief a time to enjoy the peace and satisfaction of this gracious endowment. If it is true that republics are ungrateful, it is pleasant to know that the absence of imperial and kingly patronage may be compensated by a sovereignty not less potent.

The whole course of Prof. Henry was marked by an elevation of character entirely in keeping with his intellectual force. Placed in a position where the temptation to lend the use of his name to commercial enterprises was incessant, he so studiously avoided every appearance of evil that the shadow of suspicion never rested upon him. His services to the Government in many capacities, especially in that of member of the Light-House Board, where his experiments saved it hundreds of thousands of dollars, were entirely gratuitous. His salary was paid from the Smithsonian bcquest, and he never asked the Government for a dollar on account of his services. An elevated but genial humour, a delicate poetic taste, a memory replete with anecdote, a refined intellectual face, and an impressive bcaring made him one of the most valued members of the intellectual socicty of Washington.

Prof. Henry leaves a wife and three unmarried daughters, who have been assiduous helpers in the scientific work of their father, making good to a degree the loss of an only son, whose death in early manhood was a sad disappointment of parental hopes and youthful promise.

Prof. Henry was buried May 16, in the Rock Creek Cemetery, near Georgetown, D.C. The President of the United States, the cabinet officers, diplomatic corps, and members of Congress and of the National Academy, were among the mourners.

Prof. Spencer F. Baird, long the Assistant-Secretary to the Smithsonian Institution, was, on May i7, unanimously elected by the Board of Regents as Prof. Henry's successor in the office of Secretary of that institution. No more acceptable appointment could have been made.

We express our indebtedness to Prof. Silliman, who has kindly forwarded us early sheets of an article on Prof. Henry to appear in the American Foumal of Science and Arts. From this, together with an article in the New York Nation, we have gathered most of the above details of Prof. Henry's life and work. 